\title{
Iconographic Evaluation of a Bowl with an Applique Hand from Klaros
}

\author{
[KLAROS'TAN APLİKE EL FİGÜRLÜ KASE ÜZERİNE İKONOGRAFİK \\ DEĞERLENDİRME]
}

Onur ZUNAL

\author{
Anahtar Kelimeler \\ İonia, Kutsal Alan, Klaros, Aplike, El, İonia Kasesi. \\ Keywords \\ Ionia, Sanctuary, Klaros, Applique, Hand, Ionian Cup.
}

ÖZET

Klaros'ta bulunan aplike el figürlü kâse parçası, benzerlerine özellikle kutsal alanlarda rastladı̆̆ımız oldukça ilginç bir buluntu grubunu oluşturmaktadır. Klaros örneği bir İonia kâsesinin gövdeye geçiş kısmında yer alır. Oldukça uzun yapılmış parmaklar birbirine yapışık iken baş parmak ayrı ve yukarı doğru dönüktür. Bilek kısmında bir bilezik yer alan să̆ el karşııa doğru uzanmaktadır. Kabın işlevi hakkında net bir yorum yapmak zor olsa da bu tip kaplar, libasyon veya arınma ritüeli ile ilişkili olabileceği gibi aynı zamanda sunu amaçlı da kullanılmış olabilirler. Bunun yanı sıra el figürünün ikonografik açıdan ne anlama geldiği makalenin odaklandiğı en önemli noktadır. El sadece pagan inanç için değil semavi dinler için de çok önemli bir sembol olup neredeyse tüm bu inanışlar için benzer anlamlara gelmektedir. Yaratma, koruma, kutsama, dua, kuvvet, ant, dayanıklılık, öğretme, şifacılık, yardımlaşma, sevgi, şefkat, evlilik ele verilen anlamların bazılarıdır. Klaros aplike el figürlü kâse hem kabın form ve bezeme şaması hem de elin büyük boyutlu plastik eserlerde görülen örnekleri göz önüne alındiğında İ̈ 600-575 yılları civarına tarihlendirilmektedir.

\begin{abstract}
A bowl sherd with an applique hand figure from Klaros constitutes a very interesting find group which especially finds parallels in sanctuaries. The fragment from Klaros belongs to the junction to the body of an Ionian cup. The rather long fingers are attached to each other while the thumb is separated and extended upwards. The right hand, which has a bracelet on the wrist, extends forwards. Although it is not easy to make clear comments about the function of the cup could be related to libation or initiation rituals or could be used as offerings. The iconographical meaning of the hand figure is the focal point of this paper. The hand is a very important symbol both for pagan and monotheistic religions, carrying similar meanings in nearly all of these beliefs. Some of the meanings attributed to the hand are creation, protection, blessing, prayer, force, oath, strength, instruction, healing, benevolence, love, compassion, and marriage. Based on the shape and the decoration scheme of the cup and examples of hands on large-scale sculptural works the bowl with an applique hand from Klaros is dated to about 600-575 BC.
\end{abstract}

Klaros, located in the Menderes district of Izmir Province, is one of the most significant sanctuaries of pagan religion and the oldest known prophecy center, not only for Ionia, but for the whole known ancient world. ${ }^{1}$ This paper aims to provide an iconographic evaluation of

1 Especially the excavations between 2001-2010 yielded numerous earthenware and metal artifacts dating to various phases of the Mycenean period. Şahin 2012: 264-269. an applique hand on a fragment of Ionian cup unearthed during the 3 rd season excavations in Klaros between 1988-1997. ${ }^{2}$ The ceramics with

2 The cup was unearthed during the excavations in 1997, in the 13th layer of Grid 4BC. This is the area where the monument of L. Valerius Flaccus, son of Lucius was found. In the excavations of the same year two kouroi were found in the same area Genière 1998, pl. 1. Area numbered 15. In the current excavations the monument of L. Valerius Flaccus is located in the sector named Bat1 Onur An1t1 (B.O.A.). This 
applique hands are a quite interesting group of finds mostly preserved in fragmentary examples and usually coming from sanctuaries. Specimens of this type were either not found in large quantities or not published, therefore a detailed iconographic analysis of examples of this type has not been made. In this regard the example from Klaros will introduce a unique artwork and will provide a valuable contribution to the studies on sanctuaries and iconography.

The applique hand is positioned immediately below the non-preserved mouth of the Ionian cup, at the junction to the body. The depiction on the bowl belongs to a right hand. The hand is placed below the everted mouth, between dark colored, thin and thick bands. A bracelet is seen on the wrist. The fingers are rather long, with the thumb running over the upper band. The rest of the fingers are closed together making the hand extend forward.

As mentioned above, although examples of this type are lesser known, in terms of iconography numerous meanings were attributed to the hand in various societies and religions. The hand has an extremely important meaning not only for pagan beliefs and life but also for all monotheistic religions. This paper will mainly focus on the iconographical meaning of the hand and the possible uses of the bowl in subject.

The meanings attributed to the hand as a universal figure are nearly infinite. It contains the meanings of command, protection, creation, blessing, prayer, force, oath, strength, and instruction. The hand is also related to healing, love and compassion and a helping hand is given to those in need. ${ }^{3}$

sector lies on the south of the Hellenistic Temple of Apollo Klarios. Following the French excavations, the new excavations in Klaros began by a team under the direction of Prof. Dr. Nuran Şahin. During these excavations, a sacred road with two construction phases dating to the Archaic Period was unearthed in the level where the cup was found and to the west of the monument. For detailed information on the sacred road see Şahin and Debord 2011: 174, fig. 15. The early phase of the two-phased sacred road dates to the 7 th century $\mathrm{BC}$ and it was uninterruptedly used until the 6 th century BC, when a new road was constructed above it. This second road was used until the middle of the 4th century BC. Y1lmaz 2008: 253.

3 Wilkinson 2011: 116. Uyan Dur mentions that the wrist symbolizes the intervention of God in affairs on Earth or the indication of his approval. Uyan Dur 2015, 22.
Monotheistic religions have attributed similar meanings to the hand, which is used as a kind of symbol. This symbol is found as Hamsa in Judaism and the Hand of Fatima in Islam. Khamsa (Arabic), Hamesh (Jewish) express the number five. The Hand of Hamsa has meanings such as peace, happiness, prosperity, protection from evil, warding off enemies. ${ }^{4}$ In the Jewish tradition Hamsa is known as Hand of Miriam representing the sister of Moses, Miriam. ${ }^{5}$ Fatima, an important figure in the Islamic world, is the daughter of the Prophet Muhammad, the wife of Ali and mother of Hasan and Husayn. The Hand of Fatima carries three important meanings in Islam. The first is the belief in the hands ability to heal and eliminate disease. It is believed that the hand heals the diseased area through touch. The second meaning is related to nazar. It is believed that rotating the hand three times in circles around the head protects from malice. The third is the relation of the hand to prosperity, profusion, and prayer. ${ }^{6}$

According to Christianity the hand symbolizes the power and supremacy of God.7 In this regard, it is necessary to mention the famous mural made by Michelangelo on the ceiling of the Sistine Chapel. In the painting God gives / reaches his hand to Adam, the first human, bringing him to life. ${ }^{8}$ Here the hand is in the position of the creator. Besides this, the Christian world has numerous narratives regarding the hand. It is always the symbol of power and kindness. In the verses of the apostles the hands provide the communication between God and patient. Lastly, the hand can be considered as a medium of embodiment. It can be interpreted as a means for the realization of the moral commitment of people. ${ }^{9}$ The use of the hand as "Dextrarum Junctio" i.e. "Marriage Symbol" in Christianity was inherited from the Roman tradition. This tradition is known to have been applied in Christian marriages between the 13th and 14th centuries AD. The priest fulfils the task of connecting the right hands of the

\footnotetext{
4 Ahmadi 2013: 779.

5 Karesh and Hurvitz 2006: 197

6 Işık 2017: 29. Uyan Dur 2015: 22.

7 Uyan Dur 2015: 22.

8 Jacquet 2011: 12. Uyan Dur 2015: 23.

9 Jacquet 2011: 13.
} 
marrying couple. Until the 14 th and 15 th centuries this gesture contained two meanings: it did not only represent the transition of the maiden form the world under the authority of the father to the one of the husbands but also symbolized her commitment to her husband. In the 14th and 15th centuries in connection to the evolution of mental power this symbol gradually changes in meaning and can be described as the mutual commitment of the spouses and their duties for each other. ${ }^{10}$

The hand was considered as the most powerful means for praying by the Romans, who were very pious. According to G. Dumézil in a way it means that all rights and any legal action, any sworn or unsworn contract or commitment are under the guarantee of the gods. Servius mentions that specific body parts are related to gods or goddesses. According to this the body above the knees is divided into religious parts; he notes that the knees (Misericordia), ears (Memoria "memory"), forehead (Genius) and hands should not be forgotten. Plinius also states that "The hand is the throne of Fides, goddess of prayer / orison". Fides was a goddess in the Roman pantheon, symbolizing the right hand, i.e. concord. In marriage this manifests that the connection of the bride and groom's hands is their "mutual legal obligation". At the same time, it means that the maiden enters the authority of her husband "as husband, friend, guardian and father". A sarcophagus dating to the 2 nd century AD depicts a Dextrarum Junctio scene where the Pronuba (Mother Superior) embraces a married couple who have their right hands connected. Also, sometimes Roman wedding rings were made as two joining hands. This situation reveals the importance of the hand symbol in the Roman world. ${ }^{11}$

As is the case with the Roman world, the hand is of big importance for Greek religion and social structure $^{12}$. The word used in Ancient Greek

10 Jacquet 2011: 14.

11 Jacquet 2011: 12-14. For the scene depicted on the sarcophagus see Jacquet 2011: 14.

12 The hand figure appears as an important symbol particularly associated with the cult of Sabazius. In the Greek Pantheon Sabazius is related to Dionysus, according to ancient sources, and to Zeus, according to epigraphic data. The hand belonging to this cult is was Kheir, meaning hand or arm. ${ }^{13}$ F. Mari, mentions that the hand, besides the meanings related to marriage and agreement, is related to oath and signing a contract deducing that it is connected with establishing some sort of authority or holding power. She also mentions that beginning in the Archaic period the right hand has three meanings. These are usually the opposite of left, generally used in rituals with the meaning of good luck and symbolize the mind, in other words intelligence. ${ }^{14}$ The right hand is especially emphasized in Homer's Iliad. "And no blind watch did the famed Shaker of Earth keep, but went with them in likeness of an old man, and he laid hold of the right hand of Agamemnon, son of Atreus ..." (Homer Iliad, 14. 135-137). "So spake he and did on his fair armour. And now Menelaus, would the end of life have appeared for thee at the hands of Hector, seeing he was mightier far, had not the kings of the Achaeans sprung up and laid hold of thee. And Atreus' son himself, wide-ruling Agamemnon, caught him by the right hand and spake to him ..." (Homer Iliad, 7. 104-110).

quite different from those found in Klaros and other Greek sanctuaries. In its depictions on both bronze and ceramic artworks, the little and ring fingers are closed while the other three fingers are open. S. Berndt states that Sabazius is attested in literary sources as early as the late 5th century BC, and considering archaeological data, it appears as of the Early Hellenistic Period. In terms of iconography Sabazius cannot be precisely defined until later periods, and is depicted as a bearded, elderly figure in the Roman Imperial period. In the cult of Sabazius, the hand symbolizes the underworld and life after death. Berndt 2018: 151-152. Archaeological and epigraphic data related to the cult of Dionysus in Klaros mostly belong to the Hellenistic Period. Most of these were unearthed in the Bat1 Onur Anitlar1 sector, like the bowl with an applique hand subject to this paper. It can be suggested that this area was used for the Festivals of Dionysus during the Hellenistic period. Pişkin-Ayvazoğlu 2015: 196-197. Since both cults of Dionysus and Sabazius are later than the bowl discussed in this paper, it would not be appropriate to associate the cup with either of these cults. Terracotta hand figures unearthed in the important Ionian city of Priene are an interesting find group. A. Filges mentions that there are five groups related to the hand gesture that belongs to the cult of Sabazius and remarks that the examples from Priene, with few exceptions, could not be associated with them. Filges 2015: 96-99.

13 Mari 2018: 107.

14 Mari 2018: 108. 
"She then went to her house, the daughter of Zeus, Aphrodite, but Here darted down and left the peak of Olympus; on Pieria she stepped and lovely Emathia, and sped over the snowy mountains of the Thracian horsemen, even over their topmost peaks, nor grazed she the ground with her feet; and from Athos she stepped upon the billowy sea, and so came to Lemnos, the city of godlike Thoas. There she met Sleep, the brother of Death; and she clasped him by the hand, and spake and addressed him ..." (Homer Iliad, 14. 224-231). What we understand from Homer's lines is that the hand symbolizes the strong and powerful person.

The meanings attributed to the hand figure by communities of different beliefs were mentioned above. In the light of this information, and particularly in the framework of pagan belief, let us now consider what the Klaros example can tell us and touch on similar examples.

The example from Klaros depicts the right hand. At this point let us recall the properties of creation and agreement/negotiation attributed to the right hand and mentioned above. Undoubtedly, the example from Klaros is a small sherd preserved from a bowl, therefore is there the other hand i.e. the left hand placed opposite to it? The answer to this question comes from examples from Miletus, Samos, and Naucratis. Two separate examples from Miletus depict the right and left hand, respectively. Both examples were unearthed in the sanctuary of Aphrodite. ${ }^{15}$ The finding from Samos is the best preserved compared to the rest of the examples. ${ }^{16}$ The cup is preserved in three fragments and has the depiction of a right hand with a bracelet on the wrist, just like the example from Klaros. However, the other fragment of the cup has the left hand depicted in the same way. The hands are extended to each other with lotus blossoms and a sparrow in the middle. On the reserved area below this decorative band there is a row of ordered knucklebones. Another example is the littlemaster kylix coming from the Apollo Temple in Naucratis and currently preserved in the British Museum. ${ }^{17}$ Although it is preserved in a

15 Schlotzhauer 2014: Taf. 202, 611 and Taf. 203, 613.

16 Walter-Karydi, 1973: Taf. 37, 289.

17 For images and detailed information on the example see British Museum https://www.britishmuseum.org/ small part the depiction of a left hand is visible. What is more, it is remarkable that the hand is placed directly below the handle zone. In this case the hand figures can be considered as the hands which hold or grasp the cup. Turning to the question put above, the examples from Miletus, Samos and Naucratis show that besides the right hand, the left hand and different figures / motifs could be used especially on open vessels. In this case a different approach to the iconography of the hand image should be adopted.

The scarcity of known examples makes it difficult to make clear comments on the functions of these hand-figured cups. It is possible to say that this kind of cups found especially in places such as Klaros, Miletus, Samos, and Naucratis were special productions for the sanctuaries. ${ }^{18}$ It would be a rational explanation that the examples represent the potter who created the cup or the person who made the dedication. In case we associate the examples on open vessels with the dedicants, we may suggest that this type of cups was not only used for dedications but was also related to libations. ${ }^{19}$ In summary, the opposing hand figures placed between the handles refer to holding and grasping the bowl, then drinking the liquid (wine/water) inside it and then pouring it onto the altar, that is, the libation. Afterwards, the cup and the liquid inside it are offered to the god. In that case, the instinctive approach that underlies the offering ritual is the expectation of protection by the god or the offering of gratitude to the god for the fulfillment of a wish.

Besides the abovementioned meanings and

research/collection_online/collection_object_details. aspx?objectId $=133 \overline{3} 691 \&$ partId $=1 \&$ place $=3 \overline{5} 273 \& \mathrm{pl}$ $\mathrm{aA}=35273-3-1$ \&page $=13$.

18 Besides the applique hands, knucklebones and bull heads are among the examples found in open vessels. For the example from Naucratis see Price 1924: 183, Fig. 2. For the example from Miletus see Schlotzhauer 2014: Taf. 203, 612. For the example from Rhodes see Jacopi 1929: 175, Fig. 169 and Walter-Karydi: 1973, Taf. 42, 346. For the examples from Samos see Walter-Karydi: 1973, Taf. 42, 353-357.

19 As I have stated in my doctoral thesis on Protogeometric and Geometric period ceramics from the sanctuary in Klaros, a significant part of the ceramics coming from these layers of Klaros are altar material and the ratio of open vessels among them is much higher than that of closed vessels. Zunal 2014: 134. 
functions attributed to the hand figure and the cup it is depicted on, these hands particularly might be considered to be associated with initiation. Therefore, the function of the cup may be related to some kind of initiation ritual. Fifteen inscriptions on delegations regarding the mysteria rites and initiations were found in $\mathrm{Klaros}^{20}$. These inscriptions reveal that those who arrived in Klaros made an application for a prophecy after an initiation, entered the temple, and could attend the rituals ${ }^{21}$. A. Busine states that it is not possible to know the contents and stages of the rituals in Klaros, but remarks that the delegates who were entitled to participate in these rituals were privileged. She indicates that, following the initiation, these people passed through a labirentus (a labyrinth-shaped corridor) and accessed the adyton below the temple 22 .

Besides the examples on ceramics, structurally similar examples of the applique hand are also found in sculptural artworks. The hand on the Klaros example is quite big and roughly worked. The thumb is open and pointing up whilst the rest of the four fingers are depicted closed together and nearly in similar lengths. They are not very detailed and rather left rough. Similar hand positions are found on the Kore of Auxerre in the Daedalic style ${ }^{23}$ and its contemporaries. ${ }^{24}$ The $75 \mathrm{~cm}$ high kore

20 Ferrary 2014: 122.

21 For the initiation inscription related to those coming from Kharax see Busine 2005: 193. For the initiation inscription related to those coming from Neokaisareia see Macridy 1905, 165: No. 1, 2. For the initiation inscription related to those coming from Lappa see Macridy, 1912, 46, No. 2. As mentioned in footnote no 2 of the article, the area where the bowl was unearthed is also represented by architecture and finds of the Archaic period. This raises the question of whether an altar or an area for initiations could exist in this place.

22 Busine 2005: 194.

23 Spivey 2013: 62-63. For detailed information on the Kore of Auxerre and statues in Daedalic style see also Aurigny 2012: 3-40.

24 Although hands of similar type are applied in sculptural works after about $640 \mathrm{BC}$, a similar hand structure grabs the attention in numerous sculptures dating back to the middle of the 6th century. For the example from Miletus, dated to 575-550 BC see Karakasi 2003: 156, Pl. 40, M4. For the example from Klaros dated to about 560 BC see Karakasi 2003: 56, Pl. 52. For the example from Erythrai dated to about made of limestone wears a peplos and an epiblema covers her shoulders. She is standing in an adorant position, with the left hand clearly attached to the side of the body and the right placed on the breasts. The thumb of the hand raised on the breasts is separated from the other four fingers which similar to the example from Klaros, are closed together and are nearly equal in lengths. The hand of the Kore of Auxerre, dated between 640-630 BC, and the hand on the Ionian cup from Klaros are very similar in terms of style. The hand depicted on the Ionian cup must have been made as an imitation of this type of sculptures.

Naturally, the example from Klaros does not date as early. Considering that the stylistic features of large-scale sculptures were applied on figurines in a later time, we should expect the same for ceramic art. On the other hand, the form and decoration scheme of the Ionian cup are also helpful as dating criteria.

It is hard to make a clear comparison of the example from Klaros in terms of form since the only part preserved is the junction to the body below the mouth. The first examples of the Ionian cups, with short mouths, shallow bodies and short ring foots, appear in the last quarter of the 7th century BC and are particularly common in the early 6th century BC. 25 The examples from Naucratis classified under Group DD as South Ionian productions are dated to the second and third quarters of the 6th century BC. ${ }^{26}$ Another example is a grave good unearthed in the Akpinar Necropolis of Clazomenae, in a grave dated to 620-610 BC. 27 This type with a long mouth, deep body, and high conical foot, is the most common form

560-550 BC see Karakasi 2003: 157, Pl. 54-55, E1. For the example from Rentis dated to about $580 \mathrm{BC}$ see Karakasi 2003: 161, Pl. 109, AM 2530. For the example from Keratea which also wears a bracelet on the wrist and dates to about 570-560 BC see Karakasi 2003: 161, Pl. 112, Brl 1800. For the example from Eleusis dated to 525-500 BC see Karakasi 2003: 161, Pl. 119, NM 26. For the earliest of all these examples coming from Crete and dated to the mid-7th century BC see Karakasi 2003: 67, Pl. 53. Louvre 3098.

25 Cook and Dupont 1998: 131, Fig. 18.1b.

26 Schlotzhauer and Villing 2006: 61-62, Fig. 23. For the table of clay analysis and dating data see also 55, table 1.

27 Hürmüzlü 2003: 349, Fig. 4. 20/5. 
among the Ionian cups. The first examples appear around $600 \mathrm{BC}$ and are especially prevalent in the second quarter and the middle of the 6th century BC. ${ }^{28}$ In Naucratis, finds of this type of Ionian cups, are classified under Type 9.A of South Ionian production. Scholtzhauer Villing note that the production of examples of this type began around 590-580 BC and that the latest examples date to the second half of the 6th century BC. ${ }^{29}$ Another similar example is a grave good found in the Akpinar Necropolis in Clazomenae, in a grave dated to $600-590$ BC. ${ }^{30}$ An example among the finds of the Archaic house in Antandros dates to 600-590 BC. ${ }^{31}$ Considering the application of reserved areas and glazed bands in the interior and the exterior of the cup, the example from Klaros is similar to the Ionian cups with long mouths.

It is noteworthy that the examples of similar applique hands found in Miletus, Samos, and Naucratis, were generally applied on highrimmed and deep-bodied cups. In this regard, the example from Klaros must have been applied on a cup of this type. Therefore, considering the period of existence of similar Ionian cups in the repertoire and the examples of hand depictions in sculptural works, the Ionian cup with an applique hand from Klaros should be dated to about 600-575 BC.

\section{Catalogue}

Finding Date: Klaros 1997

Finding Place: Grid 4BC, 13th level

Height: $4.2 \mathrm{~cm}$

Width: $7.2 \mathrm{~cm}$

Thickness: $0.4 \mathrm{~cm}$. Thickness of applique: $0.9 \mathrm{~cm}$

Clay Colour: 2.5 YR 5/4 reddish brown

Glaze Colour: 7.5 YR 2.5/1 black and 5 YR 4/3 reddish

brown

Date: 600-575 BC.

28 Cook and Dupont 1998: 131, Fig. 18.1d.

29 Schlotzhauer and Villing 2006: 61, Fig. 28.

30 Hürmüzlü 2003: 351, Fig. 16, 79/1.

31 Polat et al. 2018: 203, Fig. 2.

\section{Acknowledgements}

I am very grateful to my dear professors, especially Prof. Dr. Nuran Şahin, Prof. Dr. Gürcan Polat and Assoc. Prof. Dr. Hülya Bulut who shared their ideas with me in the creation of this paper. I would also like to thank Assist. Prof. Cennet Pişkin Ayvazoğlu and archaeologist Görkem Gökoluk for the ceramic drawing.

\section{Bibliography}

Homer, (=Homeros) İlyada, (çev. Azra Erhat - A. Kadir), Sander Yayınlar1, İstanbul. 1975.

Ahmadi 2013: A. Ahmadi, "The Hand in Art: Hamsa Hand", The Journal of Hand Surgery, 779-780.

Aurigny 2012: H. Aurigny, "Une notion encombrante dans l'histoire de la sculpture grecque: le «dédalisme»", Revue Archéologique 2012/1 (n 53), $3-40$.

BERNDT 2018: S. Berndt, "The hand gesture and symbols of Sabazios", Opuscala, Annual of the Swedish Institutes at Athens and Rome, II, 151-168.

Busine 2005: A. Busine, Paroles d'Apollon. Pratiques et traditions oraculaires dans l'Antiquité tardive (IIeVIe siècle), Leiden - Boston.

Cook and Dupont 1998: R.M. Cook, P. Dupont, East Greek Pottery, London and New York.

De La Geniere 1998: J. De La Genière, «Claros, bilan provisoire de dix campagnes de fouilles" in: Revue des Études Anciennes. Tome 100 n¹-2, 235-268.

Ferrary 2014: J. L. Ferrary, Les Mémoriaux de delegations $d u$ sanctuaire oraculaire de Claros d'après la documentation concervée dans le Fonds Louis Robert (Académie des Inscriptions et BellesLettres). Vol. I-II. Paris.

FILGes 2015: A. Filges, "Ein Felsheiligtum im Stadtgebiet von Priene. Privater Kult im öffentlichen Raum?". in: K. Sporn, S. Ladstätter, M. Kerschner (Hrsg.), Natur - Kult - Raum, Akten des Internationalen Kolloquiums Salzburg Januar 2012, Sonderschriften ÖAI 51 (Wien 2015) 81-109.

HürmüZlü 2003: B. Hürmüzlü, Klazomenai Akpınar Nekropolisi. (Unpublished PhD Dissertation), Ege Üniversitesi, Sosyal Bilimler Enstitüsü, İzmir.

IşıK 2017: C. Işık, “Türk Kültür Mirasında Bir Kült Olarak Hz. Fatıma”, Sûfî Araştırmaları 16, 17-33.

JACOPI 1929: G. Jacopi, Clara Rhodos III: Scavi nella necropoli di Jalisso, 1924-1928, Bergamo.

JACQUET 2011: M. Jacquet, Les symboles de l'engagement dans les rites nuptiaux, de l'Antiquité à nos jours. Angers: Institut Albert le Grand/Ircom. 
KaraKasi 2003: K. Karakasi, Archaic Korai. The J. Paul Getty Museum, Los Angeles.

Karesh and Hurvitz 2006: S.E Karesh, M.M. Hurvitz, Encyclopedia of Judaism, J.G. Melton ed.

MACRIDY 1905: Th. Macridy, "Altertümer von Notion I", JOAI 8, 135-173.

MACRIDY 1912: Th. Macridy, "Antiquités de Notion II", ÖJh 15, 36-67.

MARI 2018: F. MARI, "Les sens de la poignée de main en Grèce ancienne du VIIIe au Ve siècle avant J.-C.", KTÈMA, Civilisations de l'Orient, de la Grèce et de Rome antiques, $\mathrm{n}^{\circ} 43$, 105-132.

Pişkin-AyvazoĞLU 2015: C. Pişkin-Ayvazoğlu, Klaros'ta Dionysos Kültü, (Unpublished PhD Dissertation), Ege Üniversitesi, Sosyal Bilimler Enstitüsü, İzmir.

Polat et al. 2018: Y. Polat, O. Zunal, S. Üney, "Pottery from an Archaic House in Antandros", in: R.G. Gürtekin-Demir, H. Cevizoğlu, Y. Polat ve G. Polat with the collaboration of Gocha R. Tsetskhladze (ed), Archaic and Classical Western Anatolia: New Perspectives in Ceramic Studies, In Memoriam Prof. Crawford H. Greenewalt Jr. Proceedings of the Second KERAMOS International Conference at Ege University, İzmir, June 3-5, 2015. Colloquia Antiqua 19, 201-230.

ŞAнiN 2012: N. Şahin, "Apollon Klarios Bilicilik Merkezi”, in: A. Çilingiroğlu, Z. Mercangöz, G. Polat (eds.), Ege Üniversitesi Arkeoloji Kazıları, 248-272.

ŞAнin and Debord 2011: N. Şahin, P. Debord, "Découvertes récentes et installation du culte d'Apollon pythien à Claros", PALLAS 87, 169-204.

Schlotzhauer 2014: U. Schlotzhauer, Die südionischen Knickrandschalen. Eine chronologische Untersuchung zu den sog. Ionischen Schalen in Milet. Erlangung des Grades eines Doktors der Philosophie, Ruhr-Universität, Bochum.

Schlotzhauer and Villing 2006: U. Schlotzhauer, A. Villing, "East Greek Pottery from Naukratis: The Current State of Research". in: U. Schlotzhauer and A. Villing (eds), Naukratis: Greek Diversity in Egypt: Studies on East Greek Pottery and Exchange in the Eastern Mediterranean, 53-68.

SPIvey 2013: N. Spivey, Greek Sculpture, Cambridge University Press.

UyAN Dur 2015: B.İ. Uyan Dur, "Use of Hand as a Metaphoric Image in Poster Design". Global Journal of Arts Humanities and Social Sciences, 3 (1), 19-28.

WALTER-KARYd 1973: E. Walter-Karydi, Samische Gefässe des 6. Jahrhuderts v. Chr., Samos 6, 1, Bonn.

WiLkinson 1973: K. Wilkinson, Kökenleri ve Anlamlarıyla Semboller ve İşaretler, Binlerce Yıllık Görsel Bir Yolculuk, Alfa Yayınları, İstanbul.
Yilmaz 2008: F. Yılmaz, "Apollon Klarios Kutsal Alanındaki 'Kutsal Yol'un Seramik Buluntulara Göre Tarihlendirilmesi”, ADerg 12, 247-268.

Zunal 2014: O. Zunal, Klaros Protogeometrik ve Geometrik Dönem Seramikleri (Unpublished PhD Dissertation), Ege Üniversitesi, Sosyal Bilimler Enstitüsü, İzmir.

Makale Gönderim Tarihi: 26.06.2021

Makale Kabul Tarihi: 07.09.2021

\section{ONUR ZUNAL}

Orcid ID: 0000-0003-3074-7132

Ege Üniversitesi, Edebiyat Fakültesi, Arkeoloji Bölümü,Klasik Arkeoloji ABD,

İzmir/TURKEY.

onur.zunal@ege.edu.tr 

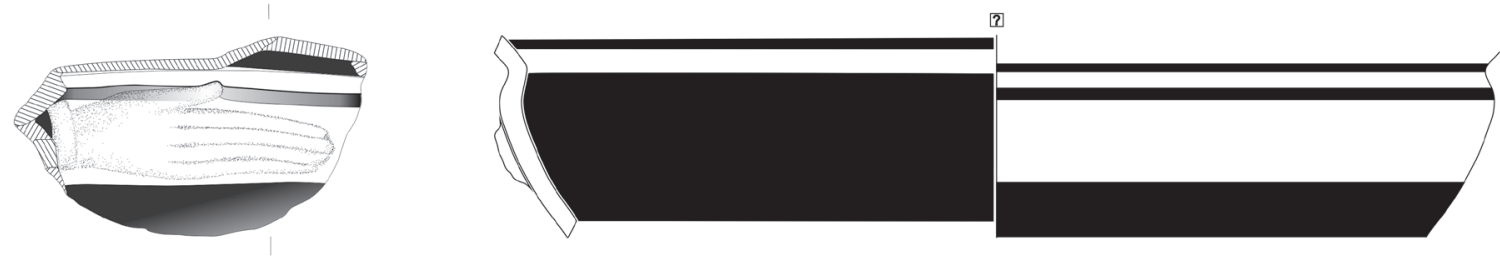

$0 \quad 5 \mathrm{~cm}$

Fig. 1. A Bowl with an Applique Hand.
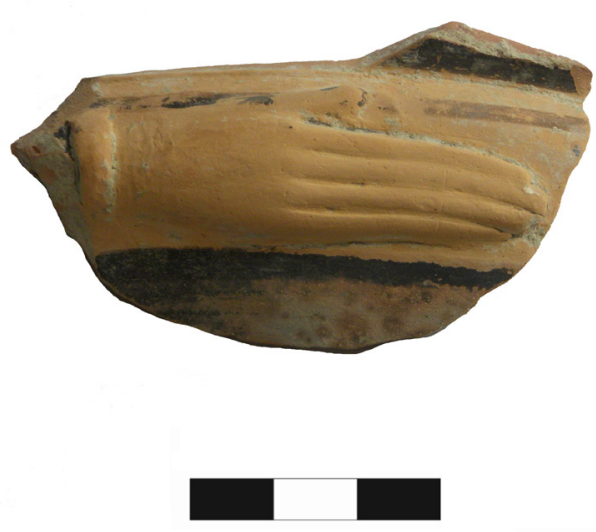

Fig. 2. Detail of the applique. 